\title{
Donor-Derived Cell-Free DNA (ddcf-DNA) and Acute Antibody-Mediated Rejection in Kidney Transplantation
}

\author{
Vishal Jaikaransingh *(D) and Pradeep V. Kadambi \\ Department of Medicine, Division of Nephrology, University of Florida, 655 West 8th Street, C290, \\ Jacksonville, FL 32209, USA; pradeep.kadambi@jax.ufl.edu \\ * Correspondence: vishal.jaikaransingh@jax.ufl.edu; Tel.: +1-904-244-4509; Fax: +1-904-244-2165
}

check for updates

Citation: Jaikaransingh, V.; Kadambi, P.V. Donor-Derived Cell-Free DNA (ddcf-DNA) and Acute Antibody-Mediated Rejection in Kidney Transplantation. Medicina 2021, 57, 436. https://doi.org/ 10.3390/medicina57050436

Academic Editor: Michal Nowicki

Received: 14 March 2021

Accepted: 26 April 2021

Published: 1 May 2021

Publisher's Note: MDPI stays neutral with regard to jurisdictional claims in published maps and institutional affiliations.

Copyright: (C) 2021 by the authors. Licensee MDPI, Basel, Switzerland. This article is an open access article distributed under the terms and conditions of the Creative Commons Attribution (CC BY) license (https:/ / creativecommons.org/licenses/by/ $4.0 /)$.

\begin{abstract}
Monitoring kidney transplant recipients for evidence of allograft rejection is essential to lower the risk of graft loss. The traditional method relies on serial checks in serum creatinine with a biopsy of the allograft if dysfunction is suspected. This is invasive, labor-intensive and costly. As such, there is widespread interest in the use of biomarkers to provide a noninvasive approach to detecting allograft rejection. One such biomarker is donor-derived cell-free DNA (ddcf-DNA). Here, we review the methodology for the determination of the amount/fraction of ddcf-DNA, evaluate the available data of its use in kidney transplantation and render an opinion in the clinical decision-making of these patients.
\end{abstract}

Keywords: donor-derived cell-free DNA; cell-free DNA; kidney transplantation; antibody-mediated rejection

\section{Introduction}

Early studies involving cell-free DNA (cf-DNA) were performed in the 1970s in patients with cancer [1]. In the field of solid organ transplantation, donor-derived cell-free DNA (ddcf-DNA) was first reported in the 1990s [2,3]. In two independent publications, Lo et al. [2] and Zhang et al. [3] described the presence of ddcf-DNA by the detection of $Y$ chromosomal DNA of male donors in the serum and urine, respectively, of female recipients. Since then, advances in the field have allowed for detection using commercially available assays [4-6]. The amount of donor-derived cell-free DNA is usually expressed as a percentage of the total cell-free DNA present. These assays do not require genotyping of the donor or the recipient [7]. The technology involves the detection of disparate single nucleotide polymorphisms (SNPs) across the whole genome and allows for the separation of the DNA derived from two individuals, and is known as genome transplant dynamics (GTD). Elevated levels of ddcf-DNA point to injury of the allograft and in some patients can suggest acute rejection.

\section{Determination of ddcf-DNA}

The methods available for the detection and quantification of ddcf-DNA in recipient plasma utilize the polymerase chain reaction (PCR). The options include real-time PCR, droplet digital PCR and massive parallel sequencing, also known as next-generation sequencing (NGS) [8,9]. Digital PCR and NGS do not require donor genotyping and they assess for a single nucleotide polymorphism for which the recipient is homozygous for a particular allele but the donor is not [7]. Both methodologies have been validated clinically and are utilizing commercially available assays.

At this time, there is no standardization for targeted SNPs in commercially available assays and the targets vary. Two NGS assays, AlloSure (Care Dx, Inc., Brisbane, CA, USA) [4,5] and Prosepera (Natera, Inc., San Carlos, CA, USA) [6] target 266 SNPs and 1392 SNPs, respectively. Melancon et al. compare the performance of these assays in a small single-center study involving 76 transplant recipients [10]. The study participants had a paired blood draw with one sample being allocated to each assay. The results of 
the each assay were correlated with the biopsy of the allograft scored using the Banff 2017 classification. Both assays were not statistically different with respect to specificity, sensitivity and positive and negative predictive values. Allosure, however, demonstrated a shorter turnaround time for $75 \%$ of patients from the blood draw to a result; and when compared with that of Prosepera, the difference was at least one day.

\section{The Kinetics of ddcf-DNA after Kidney Transplantation}

The vast majority of cf-DNA arises from hematopoietic cells undergoing apoptosis [11,12]. Only a small amount comes from solid organs [13]. It appears to be cleared rapidly from plasma with a reported half-life ranging from $16 \mathrm{~min}$ to $13 \mathrm{~h}$ in studies looking at the rate of disappearance of fetal cell-free DNA from maternal plasma [14,15].

Following kidney transplantation, ddcf-DNA decreases rapidly in the recipient plasma and this is reflected in a decline in the percentage of cf-DNA, which is donor-derived as compared to recipient-derived. Gielis et al. [16] evaluated the change in plasma ddcf-DNA in 42 stable kidney transplant recipients using NGS in a cohort which included both living and deceased donors (7 living donors and 35 deceased donors). They demonstrated an exponential decline from a median of $10.2 \%$ of ddcf-DNA (range $2.6 \%$ to $41.9 \%$ ) on the first postoperative day, with a mean of $0.46 \%(+/-0.21 \%)$ being reached on postoperative day 9.85 (+/ -5.6 days). In this cohort, the recipients of the living donor organs had lower levels of cf-DNA on postoperative day 1 when compared to the recipients of the deceased donor organs, but both groups declined to similar levels by postoperative day (POD) 10.

Shen et al. [17] conducted a similar study but in addition to 'stable' kidney transplant patients, patients with delayed graft function (DGF) were also included. Their cohort consisted of 7 living donor and 14 deceased donor recipients. In the deceased donor arm, 6 patients had DGF. The ddcf-DNA fraction declined rapidly from a median of $20.69 \%$ at $3 \mathrm{~h}$ after reperfusion to $5.22 \%$ on POD 1 ( $16.4 \mathrm{~h}$ post-transplant) to $1.98 \%$ on POD 2 and $0.85 \%$ on POD 7 . The concentration of ddcf-DNA was significantly lower on POD 2 compared to POD $1(p=0.039)$ but for all the other days there was not a statistically significant difference when compared to the prior day. The concentration of ddcf-DNA was significantly higher for patients receiving transplants from deceased donors when compared to living donors, at $44.99 \%$ compared to $10.24 \%$ at $3 \mathrm{~h}$ post reperfusion $(p<0.01)$. In addition, the rate of decline in the ddcf-DNA fraction was also slower for the recipients of the deceased donor organs. The higher fraction of ddcf-DNA persisted in the deceased donor recipients at POD 7 at $1.1 \%$ compared to $0.59 \%$ for the recipients of the living donor organs $(p<0.05)$. In addition, there was a higher concentration of ddcf-DNA in the patients who had DGF compared to those who did not, but this did not reach statistical significance.

After stabilization of the ddcf-DNA fraction after transplant, the levels can rise as a result of acute rejection but can also rise when the allograft suffers other types of injury including acute tubular necrosis [18], and in the cases of severe post-transplant infection including allograft pyelonephritis and BK virus nephropathy (BKVN) $[4,18,19]$.

\section{Ddcf-DNA and Acute Antibody Mediated Rejection}

Despite considerable interest in ddcf-DNA as a convenient, noninvasive means of diagnosing acute rejection, published data has for the most part been restricted to small cohorts with inconsistent methodologies. This is highlighted in this systematic review of the studies published through June 2018 by Knight et al. [20]. It included 739 kidney transplant recipients with 509 from papers published only in abstract form. Moreover, multiple techniques for measuring ddcf-DNA were reported. However, as commercial assays have become available there has been more consistency across publishing literature.

The AlloSure assay has been utilized in several published studies [4,21]. The "Multicenter Circulating Donor-Derived Cell Free DNA in Blood for Diagnosing Acute Rejection in Kidney Transplant Recipients" (DART) study by Bloom et al. prospectively examined 107 biopsies in 102 patients, 6 of which had active AMR4. Utilizing a 1\% cut off, there was a sensitivity of $59 \%$ and specificity of $85 \%$ with a PPV of $61 \%$ and NPV of $84 \%$ for any form 
of acute rejection. The median ddcf-DNA was $2.9 \%$ for AMR compared to $1.6 \%$ for any form of acute rejection (1.2\% for Banff 1B TCMR and 0.2\% for Banff 1A TCMR). This gave an AUC of $0.84 \%$ with $81 \%$ sensitivity and $83 \%$ specificity for AMR, and PPV and NPV of $44 \%$ and $96 \%$, respectively.

Huang et al. performed a retrospective analysis of 63 patients from a single center who had an assessment of ddcf-DNA using Allosure within 30 days of allograft biopsy [21]. The biopsies were performed "for cause" basis to assess for rejection because of graft dysfunction for the development of de novo DSA. Acute rejection was diagnosed in 34 patients of which 24 were AMR ( 2 of these were mixed AMR and TCMR). The median ddcf-DNA fraction was higher in patients with antibody-mediated rejection at $1.35 \%$, compared to $0.27 \%$ with isolated T cell-mediated rejection and $0.38 \%$ with no rejection. Of note, $28 \%$ of the patients who did not have rejection (8 of 29) had a ddcf-DNA fraction greater than $1 \%$, with one patient having a fraction as high as $5.2 \%$. Using a threshold of $0.74 \%$, the sensitivity for AMR was $100 \%$ with a negative predictive value of $100 \%$. However, using such a low threshold resulted in a specificity of $71.8 \%$ and a positive predictive value of $68.6 \%$.

Another single-center study by Zhang et al. prospectively compared 18 patients with AMR to 19 patients with stable allograft function [22]. Here, an NGS assay targeting 56,049 SNPs was used. The median ddcf-DNA fraction was $2.4 \%$ in the group with antibody-mediated rejection compared to $0.65 \%$ in the group with stable allograft function $(p<0.001)$. Using a cut off of $1 \%$, the sensitivity was $88.9 \%$, specificity was $73.7 \%$, PPV was $76.2 \%$ and NPV was $87.5 \%$. The patients without AMR but with DSA in the stable group had a median ddcf-DNA fraction of $1.09 \%$ and when this group was compared to patients with AMR, the results were not statistically significant $(p=0.074)$.

There are limited data looking at ddcf-DNA in repeat kidney transplant recipients (RKTRs). Mehta et al. examined a cohort of 12 RKTRs (11 with two allografts and 1 with three allografts in situ) from the DART study, and compared the plasma levels of ddcfDNA in these patients to a cohort of 202 single kidney transplant recipients (SKTRs) from the same study [23]. There was no documented rejection in either of these cohorts and ddcf-DNA was checked as part of surveillance. It was found that serum ddcf-DNA levels were significantly higher in the RKTRs group when compared to the SKTRs group $(0.29 \%$ vs. $0.19 \%$, respectively, $p<0.001)$. In the same study, the authors also evaluated serum ddcf-DNA levels in 11 RKTRs (9 patients with two, 1 patient with three and 1 patient with four kidney allografts in situ) from the DART study who had a kidney biopsy of their most recently transplanted allograft for a clinical indication. Within this cohort, 6 patients were diagnosed with rejection ( 2 TCMR and 4 AMR) and 5 had no rejection findings in the biopsy. The ddcf-DNA in RKTRs with rejection was higher than in RKTRs without rejection (median $1.36 \%$ vs. $0.41 \%$, respectively, $p=0.009$ ). Of note, the AlloSure method that was used in this study to determine ddcf-DNA levels does not require genotyping of the donor(s). As such, it does not distinguish which allograft(s) may have contributed to the total cf-DNA measured. Hence, ongoing inflammation in prior allografts could be a confounder resulting in higher levels of cf-DNA at the baseline in patients with RKTRs.

Pediatric kidney transplant patients are a special population where avoidance of a kidney biopsy in favor of a less invasive approach may be desired because of the potential distress. Unfortunately, data for this patient population are also extremely limited. Puliyanda et al. examined 67 pediatric kidney transplant recipients who underwent transplantation at two centers between October 2017 and October 2019 [24]. During that time, the patients underwent an assessment of ddcf-DNA using the AlloSure assay, either as part of routine monitoring (19 patients) or in response to a clinical suspicion of rejection (48 patients). In the cohort where there was clinical suspicion of rejection, $21(43.8 \%)$ patients had a ddcf-DNA of $>1 \%$ and all underwent biopsy. All the biopsies showed evidence of rejection (22.9\% AMR, 4.2\% TCMR and 16.7\% mixed AMR and TCMR). In addition, 7 patients underwent a biopsy with a ddcf-DNA of $<1 \%$. Of these, 3 patients showed evidence of rejection (1 each of AMR, TCMR and mixed AMR and TCMR) and 4 had no 
rejection in the biopsy. The ddcf-DNA fraction of $>1 \%$ had a sensitivity of $86 \%$ and a specificity of $100 \%(p=0.002)$ for the diagnosis of acute rejection.

Collectively, these studies indicate that with rejection, particularly AMR, the ddcfDNA fraction in plasma rises. This elevation, however, is not exclusive to rejection. Gielis et al. used an NGS assay targeting 1027 SNPs in 107 patients with 792 longitudinally collected blood samples. Their cut off was set at a ddcf-DNA fraction of $0.88 \%$ and $13 \%$ of the samples had fractions above the cut off. The increases in the ddcf-DNA fraction were significantly associated with acute rejection $(p=0.017)$, AT $(p=0.011)$ and acute pyelonephritis $(p=0.032)$. The AUC for an acute rejection of 0.64 was no different than that of serum creatinine. The sensitivity and specificity for ddcf-DNA were $38 \%$ and $85 \%$, respectively.

Table 1 summarizes the studies assessing ddcf-DNA in plasma for the diagnosis of acute rejection using commercially available assays.

Table 1. Studies assessing ddcf-DNA in plasma for the diagnosis of acute rejection using commercially available assays.

\begin{tabular}{|c|c|c|c|c|c|}
\hline Study & Methodology & $\begin{array}{c}\text { Number of } \\
\text { Patients }\end{array}$ & $\begin{array}{c}\text { Threshold } \\
\text { (\% dd-cfDNA) }\end{array}$ & Sen/Sepc & PPV/NPV \\
\hline Bloom et al. [4] & NGS (AlloSure) & $102 \mathrm{P} / 107 \mathrm{~B}$ & $1 \%$ & $\begin{array}{l}\text { 59/85-Any } \\
\text { Rejection } \\
\text { 81/83-AMR }\end{array}$ & $\begin{array}{l}\text { 61/84-Any } \\
\text { Rejection } \\
\text { 44/96-AMR }\end{array}$ \\
\hline Sigdel et al. [6] & NGS (Prospera) & 217B & $1 \%$ & $\begin{array}{c}\text { 88.7/72.6-Any } \\
\text { Rejection }\end{array}$ & $\begin{array}{l}\text { 52/95-Any } \\
\text { Rejection }\end{array}$ \\
\hline Huang et al. [21] & NGS (AlloSure) & $63 \mathrm{P}$ & $0.74 \%$ & $\begin{array}{c}\text { 79/72-Any } \\
\text { Rejection } \\
\text { 100/71.8-AMR }\end{array}$ & $\begin{array}{c}\text { 77/75-Any } \\
\text { Rejection } \\
\text { 68.6/100-AMR }\end{array}$ \\
\hline Mehta et al. [23] & NGS (AlloSure) & $11 \mathrm{P} / 11 \mathrm{~B}$ & $1 \%$ & NR & NR \\
\hline Puliyanda et al. [24] & NGS (AlloSure) & $67 \mathrm{P} / 28 \mathrm{~B}$ & $1 \%$ & $\begin{array}{l}\text { 86/100-Any } \\
\text { Rejection }\end{array}$ & NR \\
\hline
\end{tabular}

B-number of biopsies; NR—not reported; $\mathrm{P}-$ number of patients.

\section{Discussion}

The majority of published studies demonstrate elevated levels of ddcf-DNA in acute rejection. This association seems to be strong for AMR when compared to TCMR. However, there are multiple other causes of elevated serum ddcf-DNA including infection and acute tubular necrosis. Both of these are common occurrences in a kidney transplant population. The comprehensive evaluation of published literature is confounded by small sample sizes, heterogeneity in methodologies and differences in proposed diagnostic thresholds. However, there seems to be more consistency in recently published data because of the availability of commercial assays. These assays appear to be roughly equivalent but were only compared in one study.

There has not been a randomized trial comparing the performance of donor-derived cell-free DNA to the current standard of care, and although the data outlined suggests a high NPV for ddcf-DNA in antibody-mediated rejection, studies were for the most part small and/or single center. In addition, it is unclear how these assays will perform in a group of high-risk patients, such as those with high pre-transplant titers of donor-specific antibody or in the development of de novo donor-specific antibodies after transplantation.

At this time, there is insufficient evidence to recommend using ddcf-DNA in isolation in routine clinical practice. The gold standard for diagnosis of antibody-mediated rejection remains to be biopsy of the allograft. If a clinical indication for biopsy exists, the level of ddcf-DNA below the defined threshold should not preclude biopsy. For now, ddcf-DNA measurements may still find a role clinically at times when biopsies are contraindicated. There have also been suggestions that regular monitoring of ddcf-DNA may help to detect subclinical rejection, guide an individualized approach to immunosuppression or to follow 
the response to treatment of acute rejection. At this time there is insufficient evidence for these tests to be applied routinely.

\section{Conclusions}

At its core, ddcf-DNA is an indicator of allograft injury. It is not specific for any form of rejection including antibody-mediated rejection. Elevated levels can occur in processes limited to the allograft, such as rejection and ATN but can also be elevated in systemic conditions such as malignancy and infection. There are still many unanswered questions such as the ideal methodology for determination of ddcf-DNA and the optimal threshold for the diagnosis of rejection. More data are needed, particularly randomized trials comparing ddcf-DNA to the current standard of care. At this time, no clear recommendations can be made and kidney allograft biopsy remains the gold standard for the diagnosis of antibodymediated rejection.

Author Contributions: V.J. reviewed the literature and wrote the paper; and P.V.K. provided the outline and critical review of the manuscript. All authors have read and agreed to the published version of the manuscript.

Funding: This research received no external funding.

Institutional Review Board Statement: What we've contributed is a review of the previously published literature (publicly available data). This did not involve human or animal interactions.

Informed Consent Statement: Not applicable.

Data Availability Statement: The data presented in this study are openly available (PubMed).

Conflicts of Interest: The authors declare no conflict of interest.

$\begin{array}{ll}\text { Abbreviations } \\ \text { AMR } & \begin{array}{l}\text { antibody-mediated rejection } \\ \text { acute tubular necrosis }\end{array} \\ \text { ATN } & \text { area under the curve } \\ \text { AUC } & \text { BK virus nephropathy } \\ \text { BKVN } & \text { cell-free DNA } \\ \text { cf-DNA } & \text { delayed graft function } \\ \text { DGF } & \text { donor-derived cell-free DNA } \\ \text { ddcf-DNA } & \text { donor-specific antibodies } \\ \text { DSA } & \text { genome transplant dynamics } \\ \text { GTD } & \text { negative predictor value } \\ \text { NPV } & \text { polymerase chain reaction } \\ \text { PCR } & \text { post-operative day } \\ \text { POD } & \text { positive predictor value } \\ \text { PPV } & \text { single nucleotide polymorphisms } \\ \text { SNP } & \text { T cell-mediated rejection } \\ \text { TCMR } & \end{array}$

\section{References}

1. Leon, S.A.; Shapiro, B.; Sklaroff, D.M.; Yaros, M.J. Free DNA in the serum of cancer patients and the effect of therapy. Cancer Res. $1977,37,646-650$.

2. Lo, Y.D.; Tein, M.S.; Pang, C.C.; Yeung, C.K.; Tong, K.-L.; Hjelm, N.M. Presence of donor-specific DNA in plasma of kidney and liver-transplant recipients. Lancet 1998, 351, 1329-1330. [CrossRef]

3. Zhang, J.; Tong, K.L.; Li, P.K.; Chan, A.Y.; Yeung, C.K.; Pang, C.C.; Wong, T.Y.; Lee, K.C.; Lo, Y.M. Presence of donor- and recipient-derived DNA in cell-free urine samples of renal transplantation recipients: Urinary DNA chimerism. Clin. Chem. 1999, 45, 1741-1746. [CrossRef]

4. Bloom, R.D.; Bromberg, J.S.; Poggio, E.D.; Bunnapradist, S.; Langone, A.J.; Sood, P.; Matas, A.J.; Mehta, S.; Mannon, R.B.; Sharfuddin, A.; et al. Cell-Free DNA and Active Rejection in Kidney Allografts. J. Am. Soc. Nephrol. 2017, 28, 2221-2232. [CrossRef] 
5. Stites, E.; Kumar, D.; Olaitan, O.; Swanson, S.J.; Leca, N.; Weir, M.; Bromberg, J.; Melancon, J.; Agha, I.; Fattah, H.; et al. High levels of dd-cfDNA identify patients with TCMR 1A and borderline allograft rejection at elevated risk of graft injury. Arab. Archaeol. Epigr. 2020, 20, 2491-2498. [CrossRef]

6. Sigdel, T.K.; Archila, F.A.; Constantin, T.; Prins, S.A.; Liberto, J.; Damm, I.; Towfighi, P.; Navarro, S.; Kirkizlar, E.; Demko, Z.P.; et al. Optimizing Detection of Kidney Transplant Injury by Assessment of Donor-Derived Cell-Free DNA via Massively Multiplex PCR. J. Clin. Med. 2018, 8, 19. [CrossRef]

7. Sharon, E.; Shi, H.; Kharbanda, S.; Koh, W.; Martin, L.R.; Khush, K.K.; Valantine, H.; Pritchard, J.K.; De Vlaminck, I. Quantification of transplant-derived circulating cell-free DNA in absence of a donor genotype. PLoS Comput. Biol. 2017, 13, e1005629. [CrossRef] [PubMed]

8. Grskovic, M.; Hiller, D.J.; Eubank, L.A.; Sninsky, J.J.; Christopherson, C.; Collins, J.P.; Thompson, K.; Song, M.; Wang, Y.S.; Ross, D.; et al. Validation of a Clinical-Grade Assay to Measure Donor-Derived Cell-Free DNA in Solid Organ Transplant Recipients. J. Mol. Diagn. 2016, 18, 890-902. [CrossRef] [PubMed]

9. Bromberg, J.S.; Brennan, D.C.; Poggio, E.; Bunnapradist, S.; Langone, A.; Sood, P.; Matas, A.J.; Mannon, R.B.; Mehta, S.; Sharfuddin, A.; et al. Biological Variation of Donor-Derived Cell-Free DNA in Renal Transplant Recipients: Clinical Implications. J. Appl. Lab. Med. 2017, 2, 309-321. [CrossRef] [PubMed]

10. Melancon, J.K.; Khalil, A.; Lerman, M.J. Donor-Derived Cell Free DNA: Is It All the Same? Kidney360 2020, 1, $1116-1121$. [CrossRef]

11. Lui, Y.Y.; Chik, K.-W.; Chiu, R.W.; Ho, C.-Y.; Lam, C.W.; Lo, Y.D. Predominant Hematopoietic Origin of Cell-free DNA in Plasma and Serum after Sex-mismatched Bone Marrow Transplantation. Clin. Chem. 2002, 48, 421-427. [CrossRef]

12. Snyder, M.W.; Kircher, M.; Hill, A.J.; Daza, R.M.; Shendure, J. Cell-free DNA Comprises an In Vivo Nucleosome Footprint that Informs Its Tissues-Of-Origin. Cell 2016, 164, 57-68. [CrossRef]

13. Lui, Y.Y.; Woo, K.-S.; Wang, A.Y.; Yeung, C.-K.; Li, P.K.; Chau, E.; Ruygrok, P.; Lo, Y.D. Origin of Plasma Cell-free DNA after Solid Organ Transplantation. Clin. Chem. 2003, 49, 495-496. [CrossRef]

14. Lo, Y.M.D.; Zhang, J.; Leung, T.N.; Lau, T.K.; Chang, A.M.; Hjelm, N.M. Rapid Clearance of Fetal DNA from Maternal Plasma. Am. J. Hum. Genet. 1999, 64, 218-224. [CrossRef] [PubMed]

15. Yu, S.C.; Lee, S.W.; Jiang, P.; Leung, T.Y.; Chan, K.A.; Chiu, R.W.; Lo, Y.D. High-Resolution Profiling of Fetal DNA Clearance from Maternal Plasma by Massively Parallel Sequencing. Clin. Chem. 2013, 59, 1228-1237. [CrossRef]

16. Gielis, E.M.; Beirnaert, C.; Dendooven, A.; Meysman, P.; Laukens, K.; De Schrijver, J.; Van Laecke, S.; Van Biesen, W.; Emonds, M.-P.; De Winter, B.Y; et al. Plasma donor-derived cell-free DNA kinetics after kidney transplantation using a single tube multiplex PCR assay. PLoS ONE 2018, 13, e0208207. [CrossRef] [PubMed]

17. Shen, J.; Zhou, Y.; Chen, Y.; Li, X.; Lei, W.; Ge, J.; Peng, W.; Wu, J.; Liu, G.; Yang, G.; et al. Dynamics of early post-operative plasma ddcfDNA levels in kidney transplantation: A single-center pilot study. Transpl. Int. 2019, 32, 184-192. [CrossRef] [PubMed]

18. Whitlam, J.B.; Ling, L.; Skene, A.; Kanellis, J.; Ierino, F.L.; Slater, H.R.; Bruno, D.L.; Power, D.A. Diagnostic application of kidney allograft-derived absolute cell-freeDNAlevels during transplant dysfunction. Arab. Archaeol. Epigr. 2019, 19, 1037-1049. [CrossRef]

19. Oellerich, M.; Shipkova, M.; Asendorf, T.; Walson, P.D.; Schauerte, V.; Mettenmeyer, N.; Kabakchiev, M.; Hasche, G.; Gröne, H.; Friede, T.; et al. Absolute quantification of donor-derived cell-free DNA as a marker of rejection and graft injury in kidney transplantation: Results from a prospective observational study. Arab. Archaeol. Epigr. 2019, 19, 3087-3099. [CrossRef]

20. Knight, S.R.; Thorne, A.; Faro, M.L.L. Donor-specific Cell-free DNA as a Biomarker in Solid Organ Transplantation. A Systematic Review. Transplantation 2019, 103, 273-283. [CrossRef] [PubMed]

21. Huang, E.; Sethi, S.; Peng, A.; Najjar, R.; Mirocha, J.; Haas, M.; Vo, A.; Jordan, S.C. Early clinical experience using donor-derived cell-free DNA to detect rejection in kidney transplant recipients. Arab. Archaeol. Epigr. 2019, 19, 1663-1670. [CrossRef] [PubMed]

22. Zhang, H.; Zheng, C.; Li, X.; Fu, Q.; Li, J.; Su, Q.; Zeng, L.; Liu, Z.; Wang, J.; Huang, H.; et al. Diagnostic Performance of DonorDerived Plasma Cell-Free DNA Fraction for Antibody-Mediated Rejection in Post Renal Transplant Recipients: A Prospective Observational Study. Front. Immunol. 2020, 11, 342. [CrossRef] [PubMed]

23. Gielis, E.M.; Ledeganck, K.J.; Dendooven, A.; Meysman, P.; Beirnaert, C.; Laukens, K.; De Schrijver, J.; Van Laecke, S.; Van Biesen, W.; Emonds, M.-P.; et al. The use of plasma donor-derived, cell-free DNA to monitor acute rejection after kidney transplantation. Nephrol. Dial. Transplant. 2019, 35, 714-721. [CrossRef] [PubMed]

24. Puliyanda, D.P.; Swinford, R.; Pizzo, H.; Garrison, J.; De Golovine, A.M.; Jordan, S.C. Donor-derived cell-free DNA (dd-cfDNA) for detection of allograft rejection in pediatric kidney transplants. Pediatr Transplant. 2021, 25, e13850. [PubMed] 